\title{
PEMANFAATAN ASAP CAIR TEMPURUNG KELAPA DALAM PENGAWETAN DAGING SAPI
}

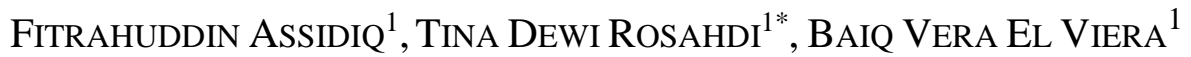 \\ ${ }^{1}$ Jurusan Kimia, Fakultas Sains dan Teknologi, UIN Sunan Gunung Djati Bandung, \\ Jl. A.H. Nasution No. 105 Cipadung, Bandung 40614 \\ *alamat email korespondensi: tina_dr@uinsgd.ac.id
}

\begin{abstract}
Informasi Artikel Abstrak/Abstract
Riwayat Naskah :

Diterima pada 7 Mei

2018

Diterima setelah

direvisi pada 7 Juni

2018

Diterbitkan pada 28

Juni 2018

Kata Kunci: Asap

Cair Tempurung

Kelapa; $G C-M S$;

Pirolisis; Daging

Sapi; TPC;.

Asap tempurung kelapa merupakan salah satu metode pengawetan secara tradisional, akan tetapi masih memiliki resiko bahaya. Potensi bahaya tersebut dapat dicegah dengan mengubah asap tempurung kelapa menjadi asap cair dengan metode pirolisis. Penelitian ini bertujuan untuk menganalisis pengaruh variasi konsentrasi dan lama waktu perendaman asap cair tempurung kelapa terhadap daya tahan daging sapi. Daya tahan daging sapi dianalisis menggunakan analisis TPC. Variasi konsentrasi asap cair tempurung kelapa yang digunakan adalah $1 \% ; 1,5 \% ; 2 \%$; dan $2,5 \% \mathrm{v} / \mathrm{v}$, sedangkan variasi lama perendaman yang digunakan yaitu 10, 20, 30 dan 40 menit. Hasil penelitian menunjukan bahwa penentuan konsentrasi asap cair optimal dilakukan dengan merendam daging sapi dalam asap cair tempurung kelapa selama 20 menit. Analisis kadar air, kadar lemak dan kadar protein dilakukan terhadap produk hasil pengawetan dan dibandingkan dengan daging sapi yang masih segar. Konsentrasi asap cair yang optimal untuk mengawetkan daging sapi diperoleh 1,5\%, dengan hasil analisis kadar air, lemak dan protein secara berturut-turut sebesar $21,79 \% ; 7,45 \%$; dan $28,48 \%$. Asap cair dengan konsentrasi 1,5\% dibuat variasi lama waktu perendaman selama 10, 20, 30 dan 40 menit. Analisis kadar air menunjukkan lama waktu perendaman optimal adalah 20 menit dengan kadar air sebesar 21,79\%, sedangkan untuk kadar lemak dan protein sebesar 7,45\% dan $28,48 \%$. Analisis total plate count (TPC) pada daging sapi yang direndam dalam asap cair dengan konsentrasi 1,5\% selama 20 menit menunjukkan bahwa daging sapi layak dikonsumsi sampai hari ketiga penyimpanan pada suhu kamar.
\end{abstract}

Keywords: Coconut Shell Liquid Smoke; GC-MS; Pyrolysis; Beef; TPC.
Coconut shell smoke is one of the traditional preservation methods, but still has a risk of danger. The potential danger can be prevented by converting coconut shell smoke into liquid smoke by the pyrolysis method. This study aims to analyze the effect of variations concentration and time of immersion of coconut shell liquid smoke on beef durability. Durability of beef was analyzed using TPC analysis. The variations concentration of coconut shell liquid smoke used were 1\%; 1.5\%; $2 \%$ and $2.5 \% \mathrm{v} / \mathrm{v}$, while the immersion time variations used were 10,20,30 and 40 minutes. The results showed that the determination of the optimal liquid smoke concentration was carried out by soaking beef in coconut shell liquid smoke for 20 minutes. Analysis of water, fat and protein content was carried out on preserved products and compared with fresh beef. The optimal concentration of liquid smoke for preserving beef is 1.5\%, with the results of analysis of water content, fat and protein respectively at $21.79 \%$; $7.45 \%$; and $28.48 \%$. Liquid smoke with a concentration of $1.5 \%$ is made variation of immersion time for 10, 20, 30 and 40 minutes. Analysis of water content showed optimal immersion time was 20 minutes with water content of $21.79 \%$, for fat and protein content was $7.45 \%$ and $28.48 \%$. Analysis of total plate count (TPC) in beef soaked in liquid smoke with a concentration of $1.5 \%$ for 20 minutes showed that beef was suitable for consumption until the third day of storage at room temperature.

\section{PENDAHULUAN}

Makanan memiliki peran yang penting dalam kehidupan makhluk hidup sebagai sumber tenaga, pertumbuhan bahkan membantu menyembuhkan penyakit. Sumber makanan yang dibutuhkan oleh tubuh harus mengandung energi, karbohidrat, protein dan vitamin. Salah satu bahan makanan sumber protein adalah daging. Daging merupakan bahan makanan yang mudah mengalami kerusakan. Daging merupakan salah satu hasil peternakan yang sangat dibutuhkan untuk memenuhi kebutuhan gizi dan protein, karena daging mengandung asam amino yang lengkap [1].

Permintaan pangan jenis hewani (daging, telur dan susu) dari hari ke hari semakin meningkat seiring dengan pertumbuhan penduduk, pertumbuhan ekonomi, perubahan pola hidup, peningkatan kesadaran gizi, dan perbaikan gizi masyarakat [2]. 
Hewan ternak yang akan dipotong memiliki beberapa persyaratan yang harus terpenuhi agar diperoleh kualitas daging yang baik. Kualitas daging yang baik dapat dilihat dari penampakan fisik berupa warna, kenampakan, bau, tingkat elastisitas dan kadar air [3]. Pada suatu produk pangan hasil ternak memiliki tingkat resiko yang tinggi terhadap kontaminasi mikroba yang berbahaya bagi kesehatan. Apabila hewan ternak tidak ditangani dengan benar setelah dipotong, bahan pangan hewani akan cepat mengalami kerusakan karena adanya mikroba yang merusak jaringan [4].

Banyak cara yang dapat dilakukan untuk meningkatkan masa simpan suatu daging, yaitu dengan pengolahan terlebih dahulu atau dengan mengawetkan daging tersebut dengan pengawet makanan. Hal ini bertujuan untuk meningkatkan masa simpan, cita rasa, dan mempertahankan nilai gizi dari daging tersebut. Salah satu metode pengawetan yang terkenal secara tradisional yaitu pengasapan. Metode ini terbukti efektif dalam meningkatan masa simpan suatu bahan pangan (daging). Seiring dengan berkembangnya teknologi, teknologi pengawetan makanan berupa pengasapan pun ikut berkembang, yaitu dengan membuat asap cair. Perkembangan pengasapan menuju asap cair ini karena adanya kekhawatiran akan zat-zat kimia yang berbahaya dalam proses pengasapan yang ikut bereaksi dalam proses tersebut, sehingga dapat menyebabkan bahaya yang tidak disadari oleh para konsumen.

Menurut Soldera et al. (2008), asap cair adalah salah satu hasil dari pirolisis kayu atau tanaman pada suhu sekitar $400^{\circ} \mathrm{C}$ [5]. Akhir-akhir ini, asap cair telah banyak digunakan oleh para pelaku industri pangan sebagai pemberi aroma, tekstur, dan citarasa yang khas pada produk pangan, seperti daging, ikan, dan keju. Asap cair mampu mengawetkan suatu bahan makanan karena dalam asap cair tekandung senyawa asam, fenolat dan karbonil [6].

Proses pengawetan makanan dengan pengasapan secara tradisional dapat digantikan dengan asap cair. Selain dinilai lebih praktis dan efisien, proses pengawetan makanan dengan asap cair lebih aman dibandingkan dengan pengasapan. Menurut hasil penelitian Fatimah dan Gugule (2009), pada produk makanan yang telah diawetkan dengan pengasapan, terkandung senyawa karsinogenik Policyclic Aromatic Hydrocarbon (PAH) [7].

Tempurung kelapa adalah salah satu bahan baku yang sangat potensial untuk dijadikan asap cair. Menurut Husseinsyah dan Mostapha (2011), dalam tempurung kelapa mengandung pentosa sebanyak $27,7 \%$, selulosa $26,6 \%$, lignin $29,4 \%$, air
$8 \%$, pelarut ekstraksi 4,2\%, uronat anhidrat 3,5\%, dan abu $0,6 \%$ [8]. Tempurung kelapa pada umumnya sering dimanfaatkan sebagai kerajinan, bahan bakar, dan bahan baku arang aktif. Pada proses pembuatan arang aktif dari tempurung kelapa akan dihasilkan asap, asap inilah yang dapat dimanfaatkan sebagai asap cair dengan mengubahnya dari fase gas menjadi fase cair dengan proses kondensasi.

Asap cair dari tempurung kelapa dapat dimanfaatkan untuk mengawetkan bahan makanan yang aman. Dalam hasil penelitian Budijanto $d k k$. (2008), dijelaskan bahwa pada asap cair tempurung kelapa tidak ditemukan senyawasenyawa Policyclic Aromatic Hydrocarbon (PAH) termasuk benzo[a]piren [9]. Secara umum, asap cair tempurung kelapa dapat dimanfaatkan sebagai bahan pengawet makanan alternatif yang aman untuk dikonsumsi, serta memberikan karakteristik sensori berupa warna, aroma, serta rasa yang khas pada produk pangan. Kandungan senyawa fenol dalam asap cair berfungsi sebagai antioksidan yang mampu memperpanjang masa simpan suatu bahan makanan dan mampu mencegah tumbuhnya suatu mikroba dalam bahan makanan tersebut.

Mikroba ialah jasad renik yang mempunyai kemampuan sangat baik untuk bertahan hidup. Jasad tersebut dapat hidup hampir di semua tempat di permukaan bumi. Mikroba mampu beradaptasi dengan lingkungan yang sangat dingin hingga lingkungan yang relative panas, dari ligkungan yang asam hingga basa. Berdasarkan peranannya, mikroba dapat dikelompokkan menjadi dua, yaitu mikroba menguntungkan dan mikroba merugikan.

Total Plate Count (TPC) adalah menumbuhkan sel mikroorganisme yang masih hidup pada media agar, sehingga mikroorganisme akan berkembang biak dan membentuk koloni yang dapat dilihat langsung dan dihitung dengan mata tanpa menggunakan mikroskop. Metode ini merupakan metode yang paling sensitif untuk menentukan jumlah mikroorganisme.Dengan metode ini, kita dapat menghitung sel yang masih hidup, menentukan jenis mikroba yang tumbuh dalam media tersebut serta dapat mengisolasi dan mengidentifikasi jenis koloni mikroba tersebut.

Pada metode ini, teknik pengenceran merupakan hal yang harus dikuasai.Sebelum mikroorganisme ditumbuhkan dalam media, terlebih dahulu dilakukan pengenceran sampel menggunakan larutan fisiologis.Tujuan dari pengenceran sampel yaitu mengurangi jumlah kandungan mikroba dalam sampel sehingga nantinya dapat diamati dan diketahui jumlah mikroorganisme secara spesifik sehingga didapatkan perhitungan yang tepat.Pengenceran 
memudahkan dalam perhitungan koloni [10]. Menurut Waluyo (2005), tahapan pengenceran dimulai dari membuat larutan sampel sebanyak 10 $\mathrm{ml}$ (campuran $1 \mathrm{ml} / 1 \mathrm{gr}$ sampel dengan $9 \mathrm{ml}$ larutan fisiologis) [11].

Dalam penelitian ini, pemanfaatan asap cair (smoke liquid) pada pengawetan daging sapi bertujuan untuk mengetahui ketahanan daging sapi jika disimpan pada suhu kamar. Tempurung kelapa dipotong kecil kecil dan dimasukan pada panci stainless steel, kemudian dilakukan proses pirolisis dan cairan yang dihasilkan diendapkan selama 1 minggu, lalu disaring. Asap cair yang telah dihasilkan diencerkan sebanyak $1 \% ; 1,5 \%$; $2 \%$; dan 2,5\%, Daging sapi direndam selama 20 menit dan dianalisis kadar air, kadar lemak, dan kadar proteinnya.

\section{EKSPERIMEN}

\section{Material}

Alat penelitian yang digunakan pada penelitian ini meliputi labu ukur merk pyrex (10 $\mathrm{mL}, 50 \mathrm{~mL}$ dan $250 \mathrm{~mL}$ ), erlenmeyer $125 \mathrm{~mL}$, cawan petri, oven, desikator, botol semprot, set alat destilasi, set alat titrasi, alat soxhlet, heating mantel, inkubator, reaktor pirolisis, neraca analitik,

Bahan yang digunakan dalam penelitian ini meliputi tempurung kelapa, daging sapi, kertas saring, akuades, NA (Nutrient Agar) dan $n$ heksana p.a.

\section{Instrumentasi}

Instrumentasi yang digunakan GC-MS Agilent Technologies 7890B-240 dan Software CFU Scope for IOS.

\section{Prosedur}

\section{Pembuatan Asap Cair Optimum Tempurung Kelapa}

Tempurung kelapa kering sebanyak \pm 2000 gram dimasukkan ke wadah stainless steel, kemudian ditutup untuk dilakukan pirolisis. Rangkaian alat kondensasi dipasang dan dilakukan pemanasan. Kondensasi diakhiri sampai asap cair tidak ada yang menetes ke dalam tabung penampung. Cairan yang diperoleh merupakan campuran heterogen antara asap cair dan tar. Cairan disimpan selama satu minggu agar tar dan pengotornya mengendap, kemudian disaring. Filtrat kemudian didestilasi pada suhu $\pm 200^{\circ} \mathrm{C}$, hasil destilasi digunakan untuk proses selanjutnya.
Sampel asap cair dikarakterisasi dengan GC-MS Agilent Technologies 7890B-240. Hasil karakterisasi didapatkan sebagai puncak-puncak. Puncak-puncak yang muncul kemudian diidentifikasi.

Asap cair tempurung kelapa tersebut, kemudian diencerkan dengan aquades hingga konsentrasi $1 \% ; 1,5 \% ; 2 \%$; dan $2,5 \%$ volume/volume.

\section{Penentuan Konsentrasi Asap Cair Tempurung Kelapa}

Daging sapi yang telah dibersihkan kemudian direndam dengan asap cair tempurung kelapa dengan konsentrasi $1 \%, 1,5 \%, 2 \%$, dan $2,5 \%$ dengan waktu perendaman selama 20 menit. Daging sapi dengan ukuran 100 gram direndam dalam $250 \mathrm{~mL}$ asap cair tempurung kelapa. Setelah 20 menit direndam dalam asap cair tempurung kelapa, daging sapi ditiriskan dan dianalisis kadar air, lemak, dan proteinnya.

\section{Penentuan Kadar Air dalam Daging Sapi}

Cawan porselen yang digunakan untuk menganalisis kadar air dicuci kemudian dipanaskan dalam oven selama 30 menit dengan suhu $105^{\circ} \mathrm{C}$. Cawan yang telah dipanaskan dimasukkan ke dalam desikator hingga dingin kemudian ditimbang sebagai berat cawan kosong. Sampel daging sapi tanpa perlakuan dan sampel daging sapi yang telah didrendam dalam asap cair tempurung kelapa masing-masing ditimbang seberat kurang lebih 5 gram, kemudian dimasukan ke dalam cawan dan ditimbang hingga diperoleh berat cawan + sampel. Cawan yang telah berisi sampel dipanaskan dalam oven selama 3 jam dengan suhu $105^{\circ} \mathrm{C}$, setelah dipanaskan cawan didinginkan dalam desikator kemudian ditimbang sebagai cawan dengan sampel yang telah hilang kadar airnya. Pemanasan dalam oven diulangi hingga memperoleh berat yang konstan.

\section{Penentuan Kadar Lemak dalam Daging Sapi}

Daging sapi yang telah direndam dalam asap cair tempurung kelapa, ditimbang sebanyak kurang lebih 5 gram dan 5 gram daging sapi tanpa perlakuan, kemudian dikeringkan dalam oven. Labu ekstraksi dikeringkan dan ditimbang sebelum digunakan, kemudian dimasukan heksana sebanyak $50 \mathrm{~mL}$ ke dalam labu ekstraksi. Sampel daging sapi yang akan dianalisis dibungkus dengan kertas saring membentuk silinder kemudian dimasukan ke dalam bejana ekstraksi. Ekstraksi dilakukan selama 2 jam. Labu didih 
yang berisi ekstrak lemak dikeringkan dalam oven pada $100^{\circ} \mathrm{C}$ selama 30 menit untuk menguapkan pelarut heksana. Setelah semua heksana menguap, labu didih didinginkan dalam desikator kemudian ditimbang. Berat lemak dinyatakan dari selisih berat labu berisi lemak dengan labu kosong.

\section{Penentuan Kadar Protein dalan Daging Sapi}

Sampel daging sapi yang telah direndam dengan asap cair tempurung kelapa seberat 5 gram dihaluskan dan dimasukan kedalam labu Kjeldahl. Pada masing-masing tabung ditambahkan 2 tablet Kjeldahl, $12 \mathrm{~mL}$ asam sulfat pekat dan $3 \mathrm{~mL} \mathrm{H}_{2} \mathrm{O}_{2}$ $30-35 \%$. Campuran dipanaskan pada suhu \pm $420^{\circ} \mathrm{C}$ selama 60 menit dan kemudian didinginkan. Setelah labu dingin pada setiap labu ditambahkan aquades sampai volume dalam tabung mencapai $80 \mathrm{~mL}$. Kemudian labu Kjeldahl dirangkai dengan alat destilasi dan labu dipanaskan perlahan-lahan hingga dua lapis cairan bercampur, kemudian dipanaskan hingga mendidih. Destilat ditampung dalam Erlenmeyer yang telah berisi $50 \mathrm{~mL}$ larutan standar asam klorida $0,1 \mathrm{~N}$. Destilasi dilakukan hingga volume destilat yang tercampur sebanyak $75 \mathrm{~mL}$. Sisa larutan $\mathrm{HCl} 0,1 \mathrm{~N}$ yang tidak bereaksi dengan destilat dititrasi dengan larutan baku $\mathrm{NaOH} 40 \%$ $0,1 \mathrm{~N}$ dengan menambahkan 5 tetes indikator fenoftalein (pp) hingga titik akhir titrasi (warna larutan menjadi merah muda).

\section{Penentuan Waktu Perendaman}

Daging sapi yang telah dibersihkan kemudian direndam dengan asap cair tempurung kelapa dengan konsentrasi asap cair tempurung kelapa $1,5 \%$ dengan waktu perendaman divariasi selama 10 menit, 20 menit, 30 menit dan 40 menit. Setelah direndam selama waktu yang ditentukan dalam asap cair tempurung kelapa, Daging sapi ditiriskan dan dianalisis kadar lemak, air, dan proteinnya.

\section{Uji Mikrobiologi}

Sebanyak $10 \mathrm{ml}$ Nutrient Agar (NA) dituangkan ke dalam cawan-cawan petri yang telah disterilkan dan didinginkan. Sebanyak 1,0061 gram sampel daging sapi yang telah direndam pada konsentrasi asap cair 1,5\% selama 20 menit dihaluskan dan dilarutkan dalam akuades hingga volumenya menjadi $10 \mathrm{~mL}$, kemudian homogen. Larutan sampel diencerkan dengan pengenceran seri pada pelarut akuades, sehingga didapatkan seri pengenceran $\left(10^{-1}, 10^{-2}, 10^{-3}, 10^{-4}\right.$, $10^{-5}$ ). Sebanyak $0,5 \mathrm{~mL}$ larutan dari masing- masing pengenceran dimasukkan ke dalam cawan petri yang telah berisi media NA (Nutrient Agar) dan diratakan dengan menggunakan batang gelas bengkok membentuk angka delapan. Sampel yang telah meresap kedalam agar (diamkan selama 1 jam), kemudian diinkubasi selama $48 \pm 2$ jam pada suhu $27^{\circ} \mathrm{C}$ (suhu ruang). Jumlah koloni dihitung dengan aplikasi penghitung koloni (CFU Scope).

\section{HASIL DAN PEMBAHASAN}

\section{Karakteristik Asap Cair}

Hasil dari pirolisis tempurung kelapa menghasilkan asap cair yang berbau sangat menyengat dan berwarna coklat pekat. Asap cair ini masih bercampur dengan tar (anti rayap) yang memiliki sifat karsinogenik sehingga asap cair ini tidak bisa langsung digunakan untuk pengawetan suatu bahan makanan. Asap cair terlebih dahulu disimpan kurang lebih satu minggu untuk mengendapkan tarnya. Setelah tar mengendap asap cair kemudian disaring untuk memisahkan residu (tar) dan filtratnya agar asap cair bisa digunakan untuk proses selanjutnya. Untuk mendapatkan hasil yang lebih aman dari zat karsinogenik, asap cair didestilasi agar terpisah dari senyawa-senyawa berbahaya yang masih terkandung dalam asap cair tersebut.

Asap cair kemudian dikarakterisasi dengan menggunakan Spektrofotometer GC-MS untuk menganalisis kandungan senyawa yang terkandung di dalamnya. Berdasarkan kromatogram pada Gambar 1, dapat diketahui kandungan senyawa yang terdapat dalam asap cair.

Tabel 1. Kandungan Senyawa dalam Asap Cair

\begin{tabular}{ccc}
\hline No & Nama Senyawa & $\begin{array}{c}\text { Kandungan } \\
\text { Senyawa (\%) }\end{array}$ \\
\hline $\mathbf{1}$ & Asam Propanoat & 54,44 \\
$\mathbf{2}$ & Fenol & 21,59 \\
$\mathbf{3}$ & Furfural & 6,67 \\
$\mathbf{4}$ & Treonina & 4,13 \\
$\mathbf{5}$ & Asam Asetat & 3,32 \\
$\mathbf{6}$ & Benzena & 2,79 \\
$\mathbf{7}$ & Caprolactam & 2,79 \\
$\mathbf{8}$ & Pirola & 2,71 \\
$\mathbf{9}$ & Asam Butanoat & 1,56 \\
\hline
\end{tabular}

Tabel 1 menunjukan bahwa senyawa asam propanoat dan fenol merupakan senyawa dominan yang terkandung dalam asap cair tempurung kelapa, dan beberapa senyawa asam lain yang teridentifikasi. Senyawa asam merupakan penyusun utama dalam asap cair, memiliki peranan sebagai antimikroba dan 
pembentuk cita rasa pada produk makanan yang diawetkan dengan asap cair. Komponen asam dapat menghambat terbentuknya spora, pertumbuhan bakteri, fungi dan aktivitas virus pada produk makanan. Sementara senyawa fenol memiliki peran sebagai antioksidan yang dapat memperpanjang masa simpan suatu produk makanan.

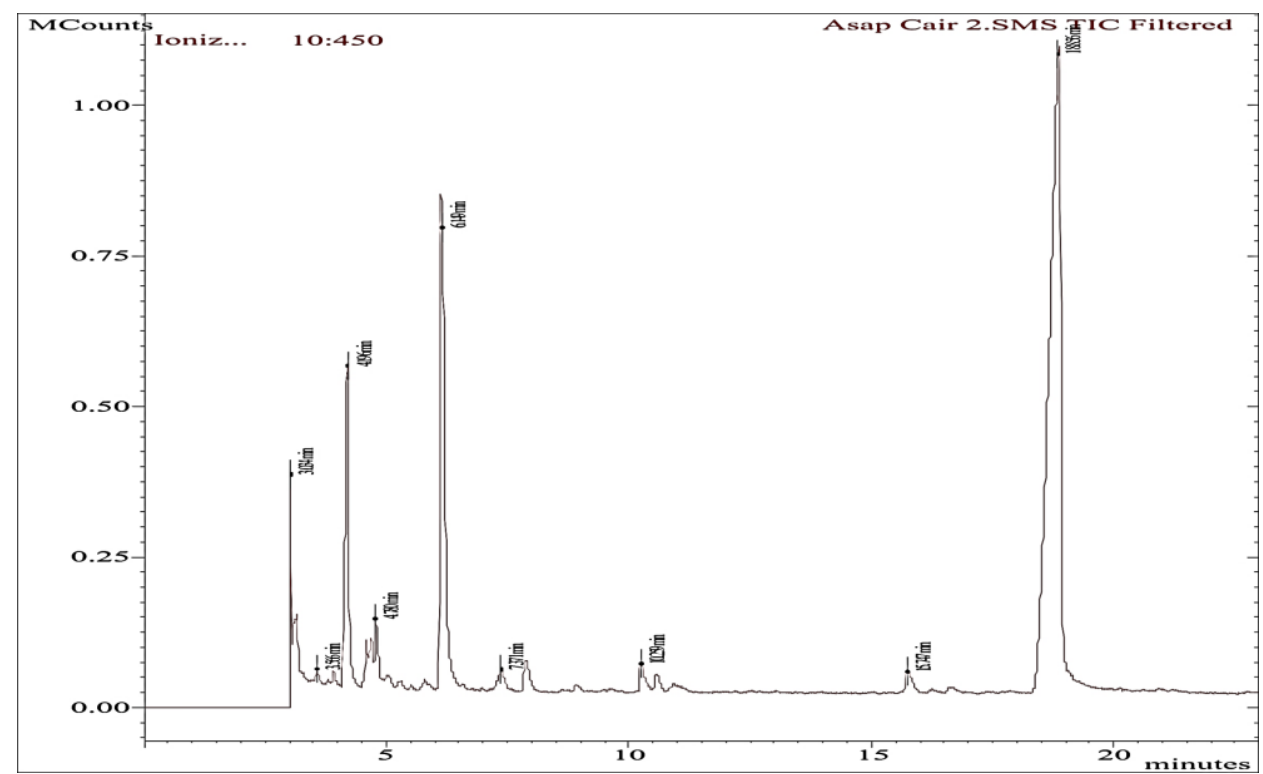

Gambar 1. Kromatogram asap cair tempurung kelapa

Mekanisme senyawa fenol dalam membunuh mikroba adalah reaksi antara asam fenolat dengan protein (dalam hal ini mikroba). Pada kondisi enzimatis dengan adanya enzim fenolase yang bekerja secara alami pada $\mathrm{pH}$ netral, asam fenolat dioksidasi menjadi kuinon yang dapat bereaksi dengan lisin dari protein yang menyebabkan protein tersebut tidak dapat digunakan secara biologis [12]. Senyawa karbonil berperan sebagai pewarna dan pemberi citarasa produk makanan.

\section{Kandungan Asap Cair Tempurung Kelapa}

Analisis kadar air dilakukan untuk mengetahui jumlah air yang terkandung dalam daging sapi setelah proses perendaman. Penentuan kadar air dalam penelitian ini menggunakan metode gravimetri. Sampel dioven pada suhu 105$110^{\circ} \mathrm{C}$, sehingga air akan menguap yang ditandai dengan konstannya berat sampel setelah pemanasan dengan lama waktu tertentu. Berat sampel setelah pemanasan menunjukan jumlah air yang terkandung dalam sampel dan kadar air dalam sampel dinyatakan dalam persen (\%). Kadar air merupakan indikator yang sangat penting pada suatu bahan pangan, karena air bisa mempengaruhi citarasa, tekstur, dan penampakan pada suatu bahan pangan. Kadar air juga merupakan indikator penentu kesegaran dan daya awet bahan pangan tersebut. Jika suatu bahan pangan mempunyai kadar air yang tinggi, maka akan mengakibatkan mudah tumbuhnya suatu bakteri, kapang, dan khamir, yang menyebabkan rusaknya suatu bahan pangan [13]. Data yang diperoleh dari analisis kadar air dalam daging sapi yang telah direndam dalam asap cair disajikan pada Tabel 2.

Tabel 2. Data hasil analisis konsentrasi

\begin{tabular}{|c|c|c|c|}
\hline $\begin{array}{c}\text { Konsentrasi } \\
\text { Asap Cair } \\
\text { Tempurung } \\
\text { Kelapa }(\%)\end{array}$ & $\begin{array}{c}\text { Kadar } \\
\text { Air (\% } \\
\text { berat } \\
\text { dalam } 5 \\
\text { gram } \\
\text { sampel) }\end{array}$ & $\begin{array}{c}\text { Kadar } \\
\text { lemak }(\% \\
\text { berat } \\
\text { dalam } 5 \\
\text { gram } \\
\text { sampel) } \\
\end{array}$ & $\begin{array}{c}\text { Kadar } \\
\text { protein } \\
\text { (\% berat } \\
\text { dalam } 5 \\
\text { gram } \\
\text { sampel) }\end{array}$ \\
\hline 0 & 28,84 & 12,69 & 26,48 \\
\hline 1 & 22,05 & 7,66 & 27,27 \\
\hline 1,5 & 21,79 & 7,45 & 28,39 \\
\hline 2 & 24,08 & 6,66 & 28,18 \\
\hline 2,5 & 22,08 & 6,77 & 30,12 \\
\hline
\end{tabular}

Dari data tersebut, kadar air dalam daging sapi segar (tanpa perendaman) yaitu sebesar $28,84 \%$ sedangkan kadar air dalam daging sapi yang telah direndam mengalami penurunan. Pada perendaman dengan konsentrasi 1,5\%, kadar air daging sapi mengalami penurunan yang paling besar yaitu sebesar $21,79 \%$. Penurunan kadar air dalam sampel daging sapi terjadi karena adanya perbedaan konsentrasi antara asap cair dan kadar air yang ada dalam sampel tersebut. Penurunan kadar air ini terjadi karena dalam asap cair terkandung senyawa fenol yang berfungsi sebagai 
antioksidan dan mampu memperpanjang masa simpan suatu bahan makanan.

Berdasarkan data yang dihasilkan pada Tabel 2, kadar lemak dalam daging sapi mengalami penurunan dengan meningkatnya konsentrasi asap cair dibandingkan dengan kadar lemak tanpa perlakuan. Hal ini disebabkan karena dalam asap cair tekandung senyawa fenol yang bersifat sebagai antioksidan, sehingga mampu menghambat terjadinya kerusakan suatu produk makanan dengan mendonorkan hidrogen sehingga dalam jumlah yang sangat kecil efektif menghambat terjadinya oksidasi lemak oleh oksigen. Menurut Shahidi (1994), komponen fenol mudah larut dalam lemak maka semakin banyak kadar lemak dalam bahan pangan makin menyengat pula aroma asap yang didapat. Daging sapi mengandung lemak yang tinggi sehingga sangat mudah teroksidasi dan menyebabkan ketengikan. Asap cair mengandung senyawa antioksidan yaitu senyawa fenol yang dapat menghambat terjadinya oksidasi lemak pada daging sapi [14].

Analisis kadar protein yang dilakukan dalam penelitian ini menggunakan metode Kjeldahl. Protein dalam suatu bahan pangan dapat mengalami kerusakan (denaturasi). Denaturasi protein terjadi akibat $\mathrm{pH}$, panas, tekanan, dan adanya bahan kimia seperti urea, alkohol dan sabun [15]. Protein akan dipecahkan atau diuraikan menjadi senyawa sederhana seperti amonia $\left(\mathrm{NH}_{3}\right)$ sehingga menimbulkan bau busuk.

Dari data yang disajikan pada Tabel II dapat dilihat bahwa kadar protein dalam daging sapi yang segar (tanpa direndam) sebesar 26,48\%. USDA menyatakan bahwa kadar protein daging sapi sebesar 24 g/100g [16]. Kadar protein daging sapi yang telah direndam dengan asap cair mengalami kenaikan yaitu berturut-turut (1\%, $1,5 \%, 2 \%$, dan 2,5\%) sebesar 27,27\%, 28,39\%, $28,18 \%$ dan $30,12 \%$. Naik turunnya kadar protein bisa terjadi karena adanya aktifitas mikroba yang menguraikan protein. Selain itu analisis kadar protein menggunakan metode Kjeldahl pada prinsipnya menghitung jumlah nitrogen total yang terkandung dalam bahan makanan. Daging sapi yang direndam dengan menggunakan asap cair memiliki kadar protein yang lebih tinggi dibanding dengan daging tanpa perlakuan dikarenakan dalam asap cair terkandung senyawa treonin yang merupakan asam amino yang diperlukan bagi tubuh manusia. Senyawa ini membuat kadar protein daging sapi yang direndam dengan asap cair memiliki kadar protein yang lebih tinggi karena dalam treonin terkandung nitrogen. Rumus molekul treonin yaitu $\mathrm{C}_{4} \mathrm{H}_{9} \mathrm{NO}_{3}$.
Dari hasil analisis kadar air, kadar lemak, dan kadar protein yang direndam selama 20 menit dapat ditentukan bahwa konsentrasi asap cair yang paling baik digunakan untuk mengawetkan daging sapi yaitu pada konsentrasi 1,5\%. Baik tidaknya suatu konsentrasi asap cair dilihat dari rendahnya kadar air, serta tingginya (minimal sama) kadar lemak dan kadar protein. Keawetan suatu bahan pangan sangat erat kaitannya dengan kadar air yang dikandungnya. Kadar air merupakan salah satu faktor penyebab terjadinya kerusakan bahan pangan, karena air merupakan media yang baik untuk tumbuh dan aktifitas mikroba perusak makanan. Suatu proses pengawetan bisa dikatakan baik jika kadar gizi sebelum dan setelah proses pengawetan tidak jauh berbeda (turun maupun naik).

Pada konsentrasi $1,5 \%$ bisa dikatakan baik karena memiliki kadar air yang paling kecil $(21,79)$, nilai kadar air tersebut sangat jauh turun dari kadar air pada daging segar. Kadar lemak dan kadar protein berturut-turut sebesar $7,45 \%$ dan $28,39 \%$. Pemilihan protein yang tinggi (minimal sama) dipilih karena protein adalah salah satu komponen gizi yang lebih dibutuhkan oleh tubuh daripada lemak.

Dalam penelitian Hani Prima Rasyadta (2013), kadar air dan kadar lemak ikan bandeng yang diawetkan dengan menggunakan asap cair tempurung kelapa mengalami penurunan. Akan tetapi penurunan tersebut tidak memiliki pola penurunan yang baik. Data yang dihasilkan dari setiap analisis kadar air, kadar lemak dan kadar protein mengalami naik turun [17].

\section{Lama Waktu Perendaman Daging Sapi}

Pada pengujian lama waktu perendaman digunakan variasi waktu. Variasi waktu lama perendaman daging sapi dalam asap cair dengan konsentrasi $1,5 \%$ yang digunakan yaitu 10 menit, 20 menit, 30 menit, dan 40 menit.

Tabel 3. Data hasil analisis lama waktu perendaman

\begin{tabular}{cccc}
\hline $\begin{array}{c}\text { Waktu } \\
\text { perendaman } \\
\text { Asap Cair } \\
\text { Tempurung } \\
\text { Kelapa } \\
\text { (menit) }\end{array}$ & $\begin{array}{c}\text { Kadar } \\
\text { Air }(\% \\
\text { berat } \\
\text { dalam 5 } \\
\text { gram } \\
\text { sampel) }\end{array}$ & $\begin{array}{c}\text { Kadar } \\
\text { lemak }(\% \\
\text { berat } \\
\text { dalam 5 } \\
\text { gram } \\
\text { sampel) }\end{array}$ & $\begin{array}{c}\text { Kadar } \\
\text { protein } \\
\text { (\% berat } \\
\text { dalam 5 } \\
\text { gram } \\
\text { sampel) }\end{array}$ \\
\hline $\mathbf{0}$ & 28,84 & 12,69 & 26,48 \\
$\mathbf{1 0}$ & 34,33 & 7,89 & 26,92 \\
$\mathbf{2 0}$ & 21,79 & 7,45 & 28,39 \\
$\mathbf{3 0}$ & 27,38 & 3,03 & 27,63 \\
$\mathbf{4 0}$ & 26,18 & 2,98 & 27,22 \\
\hline
\end{tabular}

Data pada Tabel III menunjukkan bahwa kadar air daging sapi yang paling kecil terjadi 
pada lama waktu perendaman 20 menit. Pada lama waktu perendaman 10 menit mengalami peningkatan yang cukup besar yaitu sebesar 5,49\% dari kadar air daging sapi tanpa perlakuan. Peningkatan ini bisa terjadi karena lama perendaman yang sebentar sehingga mengakibatkan air yang ada dalam sampel daging sapi belum terdorong keluar secara sempurna. Sementara pada lama waktu perendaman 30 menit dan 40 menit mengalami penurunan sekitar 1-2\%.

Hasil analisis kadar lemak daging sapi mengalami penurunan pada lama waktu perendaman setiap variasi dengan hasil berturutturut 7,89\% (10 menit), 7,45\% (20 menit), 3,03\% dan 2,98\% (40 menit). Sementara analisis kadar protein mengalami kenaikan pada daging sapi tanpa perlakuan. Pada waktu perendaman 10 menit kadar protein mengalami kenaikan yang tidak terlalu besar yaitu sebesar $0,44 \%$ dari $26,48 \%$ menjadi $26,92 \%$. Sama halnya pada waktu perendaman 30 menit dan 40 menit kenaikannya tidak terlalu besar dari 27,63\% menjadi 27,22\%.

Naik turunnya kadar protein bisa terjadi karena adanya aktifitas mikroba yang menghasilkan enzim proteolitik yang mampu mendegradasi protein protein. Degradasi protein adalah proses pemecahan molekul kompleks menjadi lebih sederhana seperti asam amino, $\mathrm{NH}_{3}$, serta komponen yang menimbulkan bau busuk seperti merkaptan, skatol dan $\mathrm{H}_{2} \mathrm{~S}$ [18].

\section{Keawetan Daging Sapi}

Kewaetan daging sapi yang telah diawetkan dengan direndam pada asap cair pada konsentrasi 1,5\% selama 20 menit diuji menggunakan analisis TPC (Total Plate Count). Data hasil analisis TPC daging sapi yang diwetkan dan daging sapi tanpa pengawetan disajikan dalam Tabel 4 dan Tabel 5.

Tabel 4. Data hasil analisis TPC Daging Sapi yang diawetkan

\begin{tabular}{ccccccc}
\hline Hari/Pengenceran & $\mathbf{1 0}^{-\mathbf{1}}$ & $\mathbf{1 0}^{-\mathbf{2}}$ & $\mathbf{1 0}^{-\mathbf{3}}$ & $\mathbf{1 0}^{-\mathbf{4}}$ & $\mathbf{1 0}^{-\mathbf{5}}$ & Rata-Rata \\
\hline $\mathbf{1}$ & 2.410 & 15.300 & 138.000 & 360.000 & 2.700 .000 & 643.142 \\
$\mathbf{2}$ & 2.520 & 19.100 & 177.000 & 450.000 & 3.000 .000 & 911.525 \\
$\mathbf{3}$ & 2.570 & 20.700 & 190.000 & 500.000 & 3.200 .000 & 977.675 \\
$\mathbf{4}$ & 3.780 & 24.000 & 238.000 & 1.500 .000 & 5.200 .000 & 1.740 .500 \\
$\mathbf{5}$ & 6.610 & 42.400 & 422.000 & 1.980 .000 & 9.000 .000 & 5.490 .000 \\
$\mathbf{6}$ & 7.550 & 77.500 & 536.000 & 2.690 .000 & 12.000 .000 & 12.000 .000 \\
$\mathbf{7}$ & 19.290 & 189.300 & 1.784 .000 & 16.700 .000 & 159.800 .000 & 35.698 .518 \\
\hline
\end{tabular}

Tabel 5. Data hasil analisis TPC Daging Sapi Tanpa Perlakuan

\begin{tabular}{ccccccc}
\hline Hari/Pengenceran & $\mathbf{1 0}^{-\mathbf{1}}$ & $\mathbf{1 0}^{-\mathbf{2}}$ & $\mathbf{1 0}^{-\mathbf{3}}$ & $\mathbf{1 0}^{-\mathbf{4}}$ & $\mathbf{1 0}^{-\mathbf{5}}$ & Rata-Rata \\
\hline $\mathbf{1}$ & 6.490 & 61.100 & 592.000 & 5.230 .000 & 49.800 .000 & 11.137 .918 \\
$\mathbf{2}$ & 7.690 & 69.800 & 631.000 & 5.980 .000 & 56.700 .000 & 12.677 .698 \\
$\mathbf{3}$ & 9.910 & 893.000 & 787.000 & 7.340 .000 & 69.800 .000 & 15.765 .982 \\
$\mathbf{4}$ & 11.800 & 98.700 & 943.000 & 9.010 .000 & 79.800 .000 & 17.972 .700 \\
$\mathbf{5}$ & 15.870 & 123.400 & 1.143 .000 & 10.540 .000 & 98.600 .000 & 22.084 .454 \\
$\mathbf{6}$ & 16.050 & 149.800 & 1.235 .000 & 11.560 .000 & 109.500 .000 & 24.492 .170 \\
$\mathbf{7}$ & 31.400 & 2.388 .000 & 1.897 .000 & 4.450 .000 & 2.368 .500 .000 & 475.453 .280 \\
\hline
\end{tabular}

Pada Tabel 4 menunjukkan pertumbuhan mikroorganisme meningkat pesat pada hari kelima yaitu sebesar $5,4 \times 10^{6} \mathrm{cfu} / \mathrm{g}$. Dari data tersebut bisa dikatakan bahwa sampel masih layak untuk dikonsumsi setelah 3 hari penyimpanan disuhu ruang, dan mulai dari hari keempat daging sapi tidak memenuhi kriteria SNI 3932:2008, yang menyebutkan bahwa jumlah mikroba dalam daging segar tidak boleh melebihi jumlah maksimum sebesar $1 \times 10^{6} \mathrm{cfu} / \mathrm{g}$. Pada hari ketujuh sampel dalam masing masing cawan petri tidak memenuhi kriteria penghitungan TPC berdasarkan SNI 01-2897-1992. Dalam standar tersebut dikatakan bahwa jumlah koloni yang memenuhi syarat yaitu 25-250 koloni. Sementara pada Tabel 5 menunjukan bahwa daging sapi tanpa perlakuan pada hari pertama sudah tidak layak konsumsi. Hasil penelitian ini sesuai dengan penelitian yang dilaporkan oleh Haras (2004), yang menyebutkan bahwa ikan cakalang yang direndam dengan asap cair tempurung kelapa selama 15 menit dan disimpan pada suhu kamar mulai mengalami 
kemunduran mutu pada hari ke-4 [19]. Sedangkan Febriani (2006), melaporkan bahwa ikan belut yang direndam dalam asap cair tempurung kelapa konsentrasi $30 \%$ selama 15 menit dapat awet pada suhu kamar sampai hari ke-9 [20].

\section{SIMPULAN}

Konsentrasi optimum asap cair tempurung kelapa 1,5\% dengan lama waktu perendaman optimum 20 menit mampu menurunkan kadar air daging sapi dari $28 \%$ menjadi $21,79 \%$, sedangkan kadar lemak dan kadar protein daging sapi setelah perendaman asap cair berturut-turut sebesar $7,4514 \%$ dan $28,48 \%$. Daging sapi yang telah direndam pada konsentrasi $1,5 \%$ selama 20 menit mampu bertahan selama 3 hari pada suhu kamar karena masih berada di bawah ambang batas jumlah mikroba yang ada dalam bahan pangan yang telah ditentukan SNI 01-2897-1992 sebesar $1 \times 10^{6} \mathrm{cfu} / \mathrm{g}$. Sementara daging sapi tanpa perlakuan pada hari pertama sudah melebihi ambang batas maksimum. Karakteristik asap cair tempurung kelapa dengan penambahan metode destilasi mengandung senyawa-senyawa seperti Treonin, Asam Butanoat, Asam Propanoat, Kaprolaktam, Furfural, Asam Asetat, Pirola, Benzen dan Fenol.

\section{REFERENSI}

[1] Siti Zulaekah, Ilmu Bahan Alam I. Surakarta, Indonesia: Jurusan Gizi Fakultas Ilmu Pendidikan Kesehatan UMS, 2002.

[2] Kastyono W and Rosegrant, "Strategi Pembangunan Pertanian dan Pedesaan Indonesia yang memihak Masyarakat Miskin," Laporan AADBTA, vol. 1, 2004.

[3] Astwan and Made, Sehat dengan Hidangan Hewani. Jakarta, Indonesia: Penebar Swadaya Bogor Press, 2008.

[4] E S Rahayu, Amankan Produk Pangan Kita: Beberapa dari Cemaran Berbahaya. Yogyakarta: Dinas Pertanian Yogyakarta, 2006.

[5] S N Soldera, Sebatianutto, and R Borrtolomeazzi, "Composition of Phenolic Compounds and Antioxidant Activity of Commercial Aqueous Smoke Flavoring," vol. 56, pp. 2727-2734, 2008.

[6] M Wijaya, Noor E, Tedja Irawadi T, and Pari G, "Karakterisasi Asap Cair dan Pemanfaatannya sebagai Biopestisida, Bionature," vol. 9, pp. 33-40, 2008.
[7] F Fatimah and Gugule S, "Penurunan Benzo[A]Pirena Asap Cair Hasil Pembakaran," 2009.

[8] S Husseinsyah and M Mosthapa, "The Effect of Filter Content On Properties of Coconut Shell Filled Polyester Composite," vol. 6, pp. 87-97, 2011.

[9] S Budijianto et al., "Identifikasi dan Uji Keamanan Asap Cair Tempurung Kelapa untuk Produk Pangan," Jurnal Pascapanen, vol. 5, pp. 32-40, 2008.

[10] S Fardiaz, Analisis Mikrobiologi Pangan, 1st ed. Jakarta: Raja Grafindo Persada, 1993.

[11] L Waluyo, Mikrobiologi Umum. Malang, Indonesia: UMM Press, 2005.

[12] R F Hurrell, Reaction of Food Protein During Processing and Storage and Their Nutritional Consequence. London: Development in Food Protein, 1984.

[13] Eddy Alifianto and Evi Liviawati, Pengawetan dan Pengolahan Ikan. Yogyakarta: Kanisius, 1989.

[14] F Shahidi, Flavor of Meat and Meat Product. New York: Autumn Press, 1992.

[15] E Yazid and L Nursanti, Penuntun Praktikum Biokimia. Yogyakarta, 2006.

[16] S D U. (2016, Mei) United States Departement of Agriculture. [Online]. https://ndb.nal.usda.gov/ndb/foods/show/761 2

[17] Prima Rasydta Hani, Penggunaan Asap Cair Tempurung Kelapa. Semarang, Indonesia: Universitas Negeri Semarang, 2013.

[18] M Tazwir Saleh and Ariyani F, Pengolahan dan Daya Awet Sosis dari Campuran Daging Cucut dan Cakalang. Jakarta: Departemen Pertanian, 1986.

[19] A Haras, Pengaruh Konsentrasi Asap Cair dan Lama Perendaman terhadap Mutu Fillet Cakalang (Katsomonus pelamis L) Asap yang disimpan Pada Suhu Kamar. Bogor: IPB, 2004.

[20] Febriani R, Pengaruh Konsentrasi Larutan Asap Cair Terhadap Mutu Belut (Monopteruis albus) Asap yang disimpan pada Suhu Kamar. Bogor: IPB, 2006. 